\title{
Isolated Esophageal İnvolvement in Pemphigus Vulgaris Confused with Esophageal Cancer
}

\author{
Pemfigus Vulgariste Özofagus Kanseri ile Karışan İzole Özofagus Tutulumu \\ (D) Munise Daye1, (D) Selami Aykut Temiz¹, (D) Mehmet Asıl2, (D) Hacı Hasan Esen³
}

${ }^{1}$ Necmettin Erbakan Univercity Meram Faculty of Medicine, Department of Dermatology, Konya, Turkey

${ }^{2}$ Necmettin Erbakan Univercity Meram Faculty of Medicine, Department of Gastroenterology, Konya, Turkey

${ }^{3}$ Necmettin Erbakan Univercity Meram Faculty of Medicine, Department of Pathology, Konya, Turkey

\begin{abstract}
Pemphigus is a disease characterized by the formation of intraepithelial blisters due to acantholysis caused by immunoglobulin $\mathrm{G}$ antibodies against the keratinocyte cell surface holding the mucous membranes and skin. While the oral mucosa is the most affected region, all body cells with multilayered horizontal epithelia such as the conjunctiva, pharynx, larynx, esophagus, vagina, penis, and anus might be affected. Although few pemphigus cases with esophageal involvement have been reported, the incidence of actual involvement is thought to be higher. Our case was guided by an external endoscopy center because of the appearance of esophagus cancer. This pre-diagnosis was excluded in the endoscopic biopsy, and lesions regressed entirely with the treatment given for pemphigus. The co-existence of pemphigus vulgaris and esophagus squamous cell carcinoma has been reported. However, it has not been previously reported that the esophageal involvement of pemphigus, as in our case, has been confused with esophageal cancer. In this case report, we present a pemphigus case with isolated esophageal involvement in a pemphigus patient in clinical remission. We found it worthy of presentation because of the confusion with esophageal cancer due to an endoscopy result from an external center.
\end{abstract}

Keywords: Pemphigus, dysphagia, esophageal involvement, endoscopy

\section{öz}

Pemfigus, mukozaları ve deriyi tutan keratinosit hücre yüzeyine karşı immünoglobulin $\mathrm{G}$ antikorların neden olduğu akantoliz nedeniyle intraepitelyal büllerin oluşması ile karakterize bir hastalıktır. Oral mukoza en çok etkilenen bölge iken, konjonktiva, yutak, larinks, özofagus, vajinal, penil ve anal mukoza gibi çok katmanlı epitelyumu olan tüm vücut alanları etkilenebilir. Pemfigus özofagus tutulumu olan az sayıda olgu bildirilmiş olmasına rağmen, gerçek tutulum insidansının daha yüksek olduğu düşünülmektedir. Olgumuz özofagus kanseri endoskopik görünümü nedeniyle dış merkezden hastanemize yönlendirilmiști. Bu ön tanı endoskopik biyopside dışlandı ve pemfigus için verilen tedavi ile lezyonlar tamamen geriledi. Literatürde, pemfigus vulgaris ve özofagus skuamöz hücreli karsinomun birlikte görüldüğü olgular bildirilmiștir. Ancak, bizim olgumuzda olduğu gibi pemfigusun özofagus tutulumunun özofagus kanseri ile endoskopik olarak karıştırıldığı bir olgu daha önce bildirilmemiștir. Bu olgu sunumunda, pemfigus vulgaris takibi sırasında izole özofagus tutulumu olan bir olgu sunuldu. Olgumuzu, dış merkez endoskopisinde özofagus kanseri ile tanıda karışıklık olması ve oral mukozal tutulum olmaksızın izole özofagus tutulumu göstermesi nedeniyle sunum yapmaya değer bulduk.

Anahtar Kelimeler: Pemfigus, disfaji, özofagus tutulumu, endoskopi

\section{Introduction}

Pemphigus is a disease characterized by the formation of intraepithelial blisters due to acantholysis caused by immunoglobulin G (IgG) antibodies against the keratinocyte cell surface holding the mucous membranes and skin (1). Pemphigus vulgaris (PV) is the most common and life-threatening subtype of pemphigus (1). While the oral mucosa is the most affected region, all body cells with multilayered horizontal epithelia such as the conjunctiva, pharynx, larynx, esophagus, vagina, penis and anus might be affected (2).
In this case report, we present a pemphigus case with isolated esophageal involvement in a pemphigus patient in clinical remission. We found it worthy of presentation because of the confusion with esophageal cancer (CA) due to an endoscopy result from an external center.

\section{Case Report}

A 55-year-old female patient complained of odynophagia and pain in her chest for about two months. The case was started proton pump inhibitor 
therapy and alginic acid at an external center with the diagnosis of esophagitis. Her symptoms did not improve. The case was diagnosed with a vegetative mass by esophagogastroduodenoscopy (EGD) and referred to gastroenterology unit of our hospital with the suspicion of esophageal CA. There was no biopsy at the external center, and the only suspicion of malignancy was noted due to endoscopic appearance and vegetative mass.

The patient was referred to our outpatient dermatology clinic from the gastroenterology department. She had been followed-up for pemphigus in our department since June 2008. No oral mucosal and skin lesions were observed on current physical examination (Figure 1). The patient's last pemphigus attack was two years ago in the form of eroded lesions in the oral mucosa. She had been in remission for one year and received prednisolone $4 \mathrm{mg}$ once daily for three months. During endoscopy, a mucosal biopsy was recommended for the differential diagnosis of esophagus CA and esophageal involvement of pemphigus.

In the EGD, multiple erosions in the form of white plaques were observed on the esophageal surface (the lesion was seen to extend from the mucosa to the lumen in a single site), which continued $7-8 \mathrm{~cm}$ from $25 \mathrm{~cm}$ (Figure 2). It was observed that the esophageal mucosa was dissected when the endoscopic biopsy was performed. The endoscopic interpretation of the gastroenterologist was in the form of esophagitis dissecans superficialis (EDS) in favor of esophageal involvement by pemphigus.

The biopsy material was interpreted as insufficient, so the level of dissociation in the histopathology could not be seen clearly. However, there were no signs of malignancy in the biopsy, and the malignancy was excluded histopathologically. The case was diagnosed with PV with isolated esophageal involvement, both clinically and endoscopically. Thirty-two mg/day prednisolone and mycophenolate mofetil $360 \mathrm{mg}$ twice a day were started. A control endoscopy was planned for the patient whose complaints regressed one month later. In the endoscopy, esophageal lesions regressed entirely (Figure 3). A gradual decrement was planned in the treatment of the patient whose lesions had regressed. Informed consent was obtained from the patient for the publication of this case report and images.

\section{Discussion}

$\mathrm{PV}$ is an uncommon autoimmune bullous disease in which bullae form as a result of acantholysis by IgG autoantibodies against intercellular antigens of stratified epithelia (1). PV can affect other mucosal surfaces such as those of the anus, genital mucosa, nasopharynx, conjunctivae, cervix, and esophagus (1,2). Although few cases with esophageal involvement of pemphigus have been reported, the incidence of actual involvement is thought to be higher (3)

Odynophagia and dysphagia are the most common symptoms of esophageal involvement. However, patients may be asymptomatic (3). In asymptomatic patients, most esophageal involvement is thought to be overlooked because endoscopy is not usually performed. Recent immunohistopathological studies have shown that esophageal involvement is higher than in previous reports (2). There are approximately 60 articles on PV involving the esophagus in the literature. The actual frequency is probably much higher. Blisters, erosions, and an easily separated esophageal mucosa (Nikolsky sign) are the most common findings on EGD. Calka et al. (2) found esophageal involvement in up to 46.15\% PV patients by endoscopy. Mignogna et al. (4) found esophageal

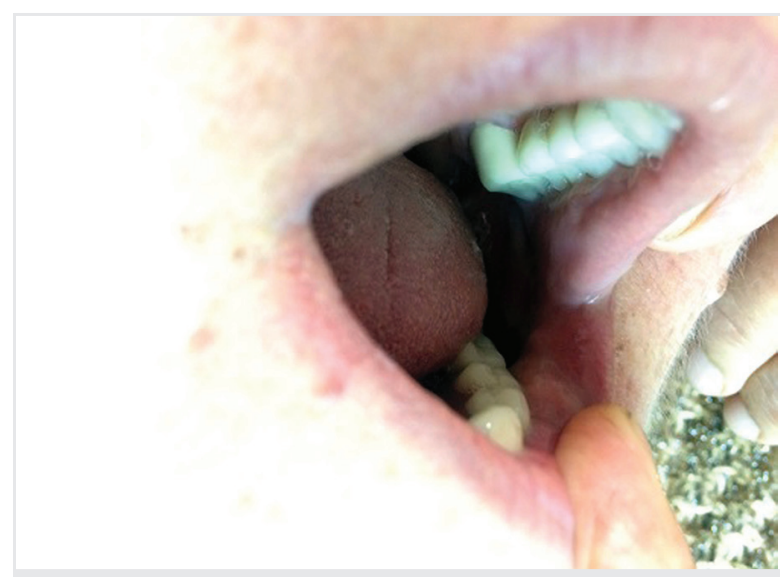

Figure 1. No oral mucosal lesions were observed in the present examination

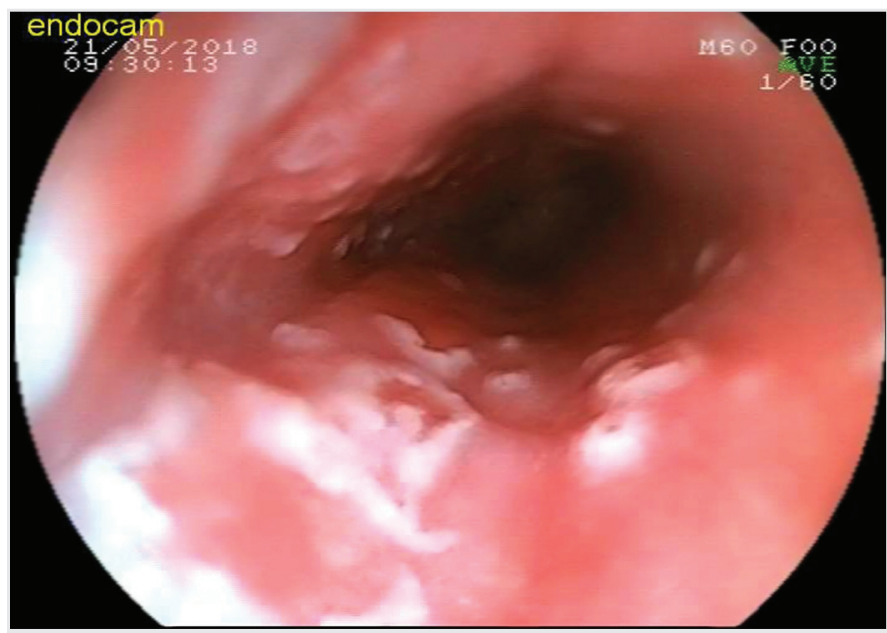

Figure 2. In the EGD, multiple erosions in the form of white plaque were observed on the esophageal surface (the lesion was seen to extend from the mucosa to the lumen in a single site), which continued $7-8 \mathrm{~cm}$ from $25 \mathrm{~cm}$ EGD: esophagogastroduodenoscopy

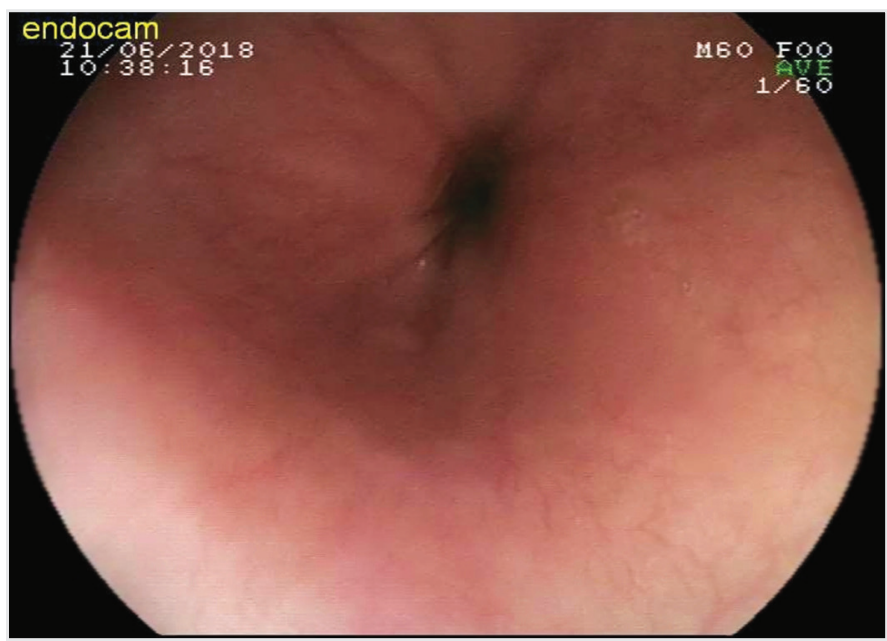

Figure 3. In the control endoscopy, esophageal lesions were completely regressed 
involvement in five out of eight patients examined. Our case was referred by an external endoscopy center due to suspicion of esophageal CA. This pre-diagnosis was excluded in the endoscopic biopsy, and lesions regressed entirely with the treatment given for pemphigus.

The co-existence of PV and esophagus squamous cell carcinoma has been reported (5). However, it has not been previously reported that the esophageal involvement of pemphigus, as in our case, has been confused with esophageal CA. We excluded the suspicion of malignancy by esophageal biopsy.

Bullous diseases may influence the esophagus in such a way that there is sloughing of the entire mucous membrane (1). The composition of such an esophageal cast has been termed EDS (2). EDS is also incorporated with trauma, immunosuppression, smoking, and medication (5). This type of involvement may not always be seen in endoscopy, which may lead to confusion with other differential diagnoses such as candidal/ infective esophagitis and steroid-induced esophagitis (6). In our case, we excluded malignancy and other preliminary diagnoses by biopsy, but because of the absence of full-thickness biopsy, we could not make a judgment about the place of decomposition and exact histopathological PV. At this stage, we endoscopically diagnosed PV in the patient, relying on the experience of the endoscopist. We also achieved a successful outcome with treatment for PV. In an endoscopy study, it was found that in skilled hands, the endoscopy was sufficient to determine the esophageal involvement of pemphigus (7). As in our case, endoscopic diagnosis can be made in those cases where there is inadequate material for a biopsy. However, the experience of the endoscopist and the suspicion of the diagnosis of pemphigus are important in these cases.

Esophageal involvement should be considered when there are symptoms such as dysphagia and odynophagia with a previous history of PV (8). The majority of patients with lesions in the esophagus are middleaged women, as in our case. Most case reports in the literature define patients with PV as having either oral or cutaneous lesions at the time of diagnosis of esophageal involvement $(9,10)$. At the same, in a study of esophageal involvement of pemphigus, oral mucosal involvement was reported in $87 \%$ of the patients (11). As in our case, isolated esophageal relapse is an unexpected condition without oral lesions.

We have described a case of PV in which the esophagus, which was previously misdiagnosed as esophagus CA, was seriously involved without skin or oropharynx involvement. Our case is valuable because it showed only isolated esophageal in a pemphigus patient in clinical remission without other skin and oral mucosa involvement. At the same time, no case has been reported in the literature in which esophageal involvement of pemphigus and esophagus CA were confused. For these reasons, we found it appropriate to publish.

\section{Conclusion}

Identification of the esophageal involvement of pemphigus may change the management requiring teamwork between dermatologists and the gastroenterologist. Endoscopic assessment is, therefore, necessary to discriminate between esophageal involvement of PV and other pathologies, which warrant significant differences in management. The endoscopic inspection should be applied carefully in talented hands for esophageal symptoms to decide the correct diagnosis and allow quick treatment.

Informed Consent: Informed consent was obtained from the patient for the publication of this case report and images.

Peer-review: Externally peer-reviewed.

Authorship Contributions: Concept - M.D., S.A.T., M.A.; Design - M.D., S.A.T., M.A.,; Data Collection or Processing - M.D., S.A.T., M.A., H.H.E.; Analysis or Interpretation - M.D., S.A.T., M.A., H.H.E.; Literature Search M.D., S.A.T., M.A.; Writing - M.D., S.A.T.

Conflict of Interest: No conflict of interest was declared by the authors.

Financial Disclosure: The authors declared that this study received no financial support.

\section{References}

1. Stanley JR. Pemphigus. Fitzpatrick's Dermatology in General Medicine. Ed. Freedberg IM, Eisen AZ, Wolff K ve ark. 6. baskı New York: Mc Graw-Hill, 2003; 558-67.

2. Calka O, Akdeniz N, Tuncer I, Metin A, Cesur RS. Oesophageal involvement during attacks in pemphigus vulgaris patients. Clin Exp Dermatol 2006; 31 515-9.

3. Bandyopadhyay N, Fass R, Yamasaki T, Hemond C. Esophageal Manifestations of Dermatological Conditions. In Pocket Handbook of Esophageal Disorders 2019; (pp. 41-46). Springer, Cham.

4. Mignogna MD, Lo Muzio L, Galloro G, Satriano RA, Ruocco V, Bucci E. Oral pemphigus: clinical significance of esophageal involvement: report of eight cases. Oral Surg Oral Med Oral Pathol Oral Radiol Endod 1997; 84: 179-84.

5. Takahashi O, Okushiba S, Kondo S, Morikawa T, Hirano S, Miyamoto M, et al. Esophageal pemphigus vulgaris with carcinoma: post-operative steroid therapy based on pemphigus-related antibodies. Dis Esophagus 2005; 18 : 413-17.

6. Hokama A, Yamamoto Y, Taira K, Nakamura M, Kobashigawa C, Nakamoto M, et al. Esophagitis dissecans superficialis and autoimmune bullous dermatoses: a review. World J Gastrointest Endosc 2010; 2: 252-6.

7. Galloro G, Mignogna M, De Werra C, Magno L, Diamantis G, Ruoppo E, et al. The role of upper endoscopy in identifying oesophageal involvement in patients with oral pemphigus vulgaris. Dig Liver Dis 2005; 37: 195-9.

8. Şeremet S, Onsun N, Danalıoğlu A, Demirkesen C, Aygın MS. The oesophageal involvement of pemphigus vulgaris patients and comparison with skin findings. Turkderm 2008; 42: 87-90.

9. de Macedo AG, Bertges ER, Bertges LC, Mendes RA, Bertges TABS, Bertges KR, et al. Pemphigus vulgaris in the mouth and esophageal mucosa. Case Rep Gastroenterol 2018; 12: 260-5.

10. Su O, Onsun N, Teker AM, Cinkaya A, Korkut AY, Seremet S, et al. Upper airway tract and upper gastrointestinal tract involvement in patients with pemphigus vulgaris. Eur J Dermatol 2010; 20: 792-6.

11. Rao P N, Samarth A, Aurangabadkar SJ, Pratap B, Lakshmi T. Study of upper gastrointestinal tract involvement in pemphigus by esophago-gastroduodenoscopy. Indian J Dermatol Venereol Leprol 2006; 72: 421-4. 